\title{
XPS AND OPTICAL PROPERTIES OF SOL-GEL PROCESSED VANADIUM PENTOXIDE FILMS
}

\author{
V. Bondarenka ${ }^{\text {a }}$, S. Kačiulis ${ }^{\text {b }}$, Z. Martūnas a ${ }^{\text {, A. Rėza }}{ }^{\text {a }}$, G.J. Babonas ${ }^{\text {a }}$, and \\ A. Pašiškevičius ${ }^{\text {a }}$ \\ ${ }^{a}$ Semiconductor Physics Institute, A. Goštauto 11, LT-01108 Vilnius, Lithuania \\ E-mail: bond@pfi.lt \\ ${ }^{\mathrm{b}}$ Institute for the Study of Nanostructured Materials (ISMN-CNR), P.O.Box 10, I-00016 Monterotondo Scalo, Italy
}

Received 9 May 2008; revised 4 December 2008; accepted 4 December 2008

\begin{abstract}
Vanadium pentoxide xerogels were prepared by using sol-gel technology. As-prepared samples of xerogels were heated up to $580 \mathrm{~K}$ in order to remove the bonded water. The chemical composition of xerogel samples and thin films has been studied by X-ray photoelectron spectroscopy (XPS). XPS data have shown that pure $\mathrm{V}_{2} \mathrm{O}_{5}$ compound was formed. After thermal treatment, in the XPS spectra the main changes occurred in the vicinity of the $\mathrm{O} 1 \mathrm{~s}$ peak due to the removal of water from xerogel. The optical properties of $\mathrm{V}_{2} \mathrm{O}_{5}$ films were studied by optical transmission and spectroscopic ellipsometry. Ellipsometric measurements have been carried out in the spectral range of $0.5-5.0 \mathrm{eV}$ at $300 \mathrm{~K}$. The changes in the optical spectra were observed after thermal annealing of as-prepared xerogel samples. The obtained data have shown that thermal treatment of $\mathrm{V}_{2} \mathrm{O}_{5}$ thin films has strongly influenced the optical transitions involving both localized and higher-lying conduction bands.
\end{abstract}

Keywords: vanadium pentoxide films, sol-gel technology, optical properties, XPS

PACS: $79.60 .-\mathrm{i}$, 81.20.Fw, 81.40.Tv, 82.70.Gg

\section{Introduction}

Vanadium pentoxide belongs to a wide class of $3 \mathrm{~d}$ transition metal oxides. This material is used as catalyst in various technological processes of organic compounds with satisfactory yield and enantioselectivity $[1,2]$. Vanadium oxides represent also promising materials in the development of optoelectronic devices like sensors, batteries, switching elements, etc. due to large electro-, photo-, and thermo-chromic effects $[3,4]$. Therefore, great attention is constantly paid to the technological procedures in the formation of vanadium oxide thin films.

Thin films of $\mathrm{V}_{2} \mathrm{O}_{5}$ were most often prepared by using sputtering [5-7] or pyrolysis [8] techniques. However, these methods require a high vacuum system and other special equipment. A more promising process for the production of thin films is the so-called wet chemistry technique or sol-gel synthesis, by means of which vanadium oxide-based compounds are produced from aqueous precursors [9-11]. It should be emphasized that the structure of vanadium pentoxide xerogels is composed of $\mathrm{V}_{2} \mathrm{O}_{5}$ blocks linked by strongly bonded water molecules $[12,13]$. Colloidal suspen- sions of $\mathrm{V}_{2} \mathrm{O}_{5}$ possess the structural features typical of lyotropic nematic crystals [14]. As a rule, anisotropic xerogel layers are formed in $\mathrm{V}_{2} \mathrm{O}_{5} \cdot n \mathrm{H}_{2} \mathrm{O}$ gels deposited and dried on the solid substrate. The average distance between $\mathrm{V}_{2} \mathrm{O}_{5}$ ribbons increases with $n$ [14].

Thus, the sol-gel synthesis process for the production of the vanadium pentoxide thin films can be described by the following steps: production of $\mathrm{V}_{2} \mathrm{O}_{5}$ gels and heating of the obtained hydrate up to the temperature ensuring the removal of water (absorbed, zeolyte type, and chemically bonded) from the xerogel.

For a non-destructive characterization of vanadium oxides, the optical studies are most often carried out. Optical properties of sputtered vanadium pentoxide thin films $[5,6,8]$ and nanocrystalline films fabricated by plasma-enhanced chemical vapour deposition [15] were investigated. Absorption data of $\mathrm{V}_{2} \mathrm{O}_{5}$ films [11] produced by sol-gel technology and optical properties of vanadium pentoxide gels [16] were also studied. The infrared measurements of $\mathrm{V}_{2} \mathrm{O}_{5}$ films fabricated on KRS5 substrates by dipcoating technique showed [17] that both the vibrational spectra of the xerogel and its change due to heat treatment depended on the precursors and the method of preparation. The aim of the present work 
was to track the changes in the electronic structure and optical properties of $\mathrm{V}_{2} \mathrm{O}_{5}$ passing from the xerogel asprepared samples to annealed solid-state films.

\section{Experimental set-up}

The vanadium pentoxide gels were prepared by dissolving the $\mathrm{V}_{2} \mathrm{O}_{5}$ powder in the $10 \% \mathrm{H}_{2} \mathrm{O}_{2}$ solution [18-20]. This exothermic reaction was carried out at $275 \mathrm{~K}$. After reaction was completed, the solution was heated up to $350 \mathrm{~K}$ for the decomposition of peroxide compounds. Produced gels were deposited on the glass substrates by screen-printing technique and dried in air at room temperature. Obtained thin films of 1.5$5.0 \mu \mathrm{m}$ thickness were heated up to $580 \mathrm{~K}$ for one hour in pure oxygen ( $p=1 \mathrm{~atm}$ ) in order to remove the major amount of water from the samples.

It should be noted that the fabricated thin films of $\mathrm{V}_{2} \mathrm{O}_{5} \cdot \mathrm{nH}_{2} \mathrm{O}$ were optically isotropic, in contrast to the films of thickness $\sim 50 \mu \mathrm{m}$ with $n<400$ [21]. It is reasonable to assume that a certain amount of water still persisted in the samples under investigation resulting in the formation of isotropic phase $(n>600$ [21]) with anisotropic droplets dispersed within an isotropic gel.

The electronic structure and chemical composition of the produced xerogel as well as the oxide thin films have been studied by XPS making use of an Escalab MkII (VG Scientific) spectrometer equipped with a double $\mathrm{Al} / \mathrm{Mg} \mathrm{K}_{\alpha}$ (1486.6 or $1253.6 \mathrm{eV}$ ) excitation source, a five-channeltron detection system and a hemispherical analyser, which was set to $20 \mathrm{eV}$ pass energy. The binding energy (BE) scale was corrected for charging effects by assigning a value of $284.6 \mathrm{eV}$ to the $\mathrm{C} 1 \mathrm{~s}$ peak. The accuracy of the relative intensities and $\mathrm{BE}$ of the measured lines were about $10 \%$ and $0.1 \mathrm{eV}$, respectively. Photoemission data have been collected and processed using a VGX-900 data system. After Shirley background subtraction, a nonlinear least-squares curve-fitting routine with a Gaussian / Lorentzian product function has been used for the analysis of XPS spectra.

The optical properties of $\mathrm{V}_{2} \mathrm{O}_{5}$ films were studied by optical transmission and spectroscopic ellipsometry technique. Ellipsometric measurements were performed at $300 \mathrm{~K}$ in the spectral range of $0.5-5.0 \mathrm{eV}$ by means of a home-made photometric ellipsometer with rotating analyzer [22] based on monochromator SPM-2 [23]. The corrections due to wandering of light spot on the photo-cathode and non-linearity of photodetector were taken into account during on-line processing. The convergence of monochromatic light beam (diam-
Table 1. Binding energy values (in $\mathrm{eV}$ ) of the main XPS peaks in $\mathrm{V}_{2} \mathrm{O}_{5}$ samples.

\begin{tabular}{cccc}
\hline Sample & $\mathrm{V} \mathrm{2} \mathrm{p}_{3 / 2}$ & $\mathrm{~V} 2 \mathrm{p}_{1 / 2}$ & $\mathrm{O} 1 \mathrm{~s}$ \\
\hline As-prepared & 517.36 & 524.90 & 530.32 \\
& & & 532.74 \\
\hline Annealed & 517.63 & 524.98 & 530.75 \\
\hline
\end{tabular}

eter $1 \mathrm{~mm}$ at small incidence angles) was $2-5^{\circ}$. In the spectral range under consideration the ellipsometric angles $\Psi$ and $\Delta$ were measured with an accuracy of $0.02^{\circ}$. The ellipsometric measurements have been performed at the angles of light incidence $\Theta$ equal to $70^{\circ}$ and $75^{\circ}$.

In the region of fundamental absorption the data of ellipsometric measurements were analysed in the approximation of a pseudodielectric function $\langle\varepsilon\rangle$ [24]. In this model the optical response of anisotropic system is considered as that for isotropic media:

$$
\langle\varepsilon\rangle=\sin ^{2} \Theta\left[\left(\frac{1-\rho}{1+\rho}\right)^{2} \tan ^{2} \Theta+1\right],
$$

where $\rho$ is the complex reflection defined as the ratio of complex amplitude Fresnel reflection coefficients $R_{p}$ and $R_{s}$ for light polarized parallel and perpendicular to the plane of light incidence, respectively, which is related to the ellipsometric angles $\Psi$ and $\Delta$ :

$$
\rho=\frac{R_{p}}{R_{s}}=\tan \Psi \exp (\mathrm{i} \Delta) .
$$

In the near-infrared region of a relative transparency, the experimental ellipsometric results were analysed in the model of a multilayer structure [25,26]. Each $i$ th layer of the structure was characterized by complex refraction index $n_{i}$ and thickness $d_{i}$. The optical response was calculated by a transfer-matrix technique. The propagation of the electromagnetic wave was modelled by introduction a 2D vector for electric and magnetic fields and taking into account the boundary conditions at the interface between layers.

\section{Results}

The XPS data for as-deposited xerogel and annealed sample are shown in Figs. 1 and 2, respectively. The binding energy (BE) values of the main XPS peaks for the $\mathrm{V}_{2} \mathrm{O}_{5}$ as-prepared xerogels and annealed thin films are presented in Table 1. As it is seen, $\mathrm{V} 2 \mathrm{p}_{3 / 2}$ and $\mathrm{V} 2 \mathrm{p}_{1 / 2}$ peaks for xerogel and annealed thin film are similar. The BE-values correspond to the $\mathrm{V}^{5+}$ state of vanadium and agree well with those reported in [2729]. The $\mathrm{O} 1 \mathrm{~s}$ peak at $\mathrm{BE}=530.32 \mathrm{eV}$ corresponds to 


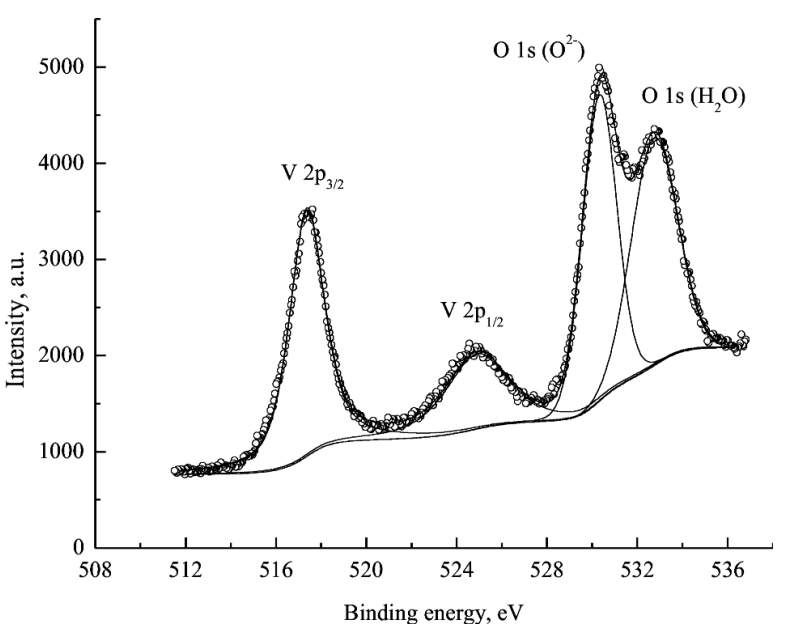

Fig. 1. XPS experimental (symbols) and modelled (curves) data for as-prepared vanadium pentoxide gel in the $\mathrm{V}-\mathrm{O}$ region.

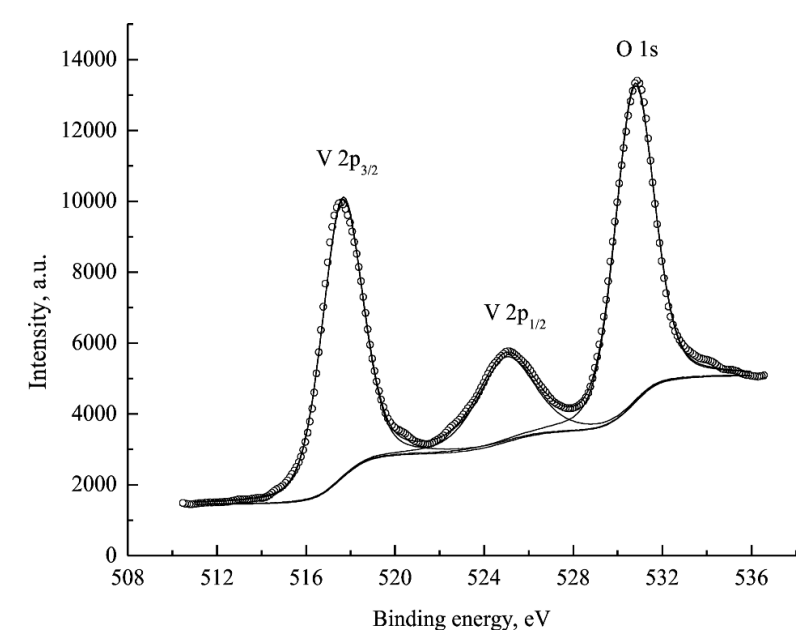

Fig. 2. XPS experimental (symbols) and modelled (curves) data for annealed vanadium pentoxide thin film.

$\mathrm{O}^{2-}$ ions in $\mathrm{V}_{2} \mathrm{O}_{5}$ [30]. The second less intense XPS line of oxygen at $532.74 \mathrm{eV}$, which has been observed in as-prepared films, can be attributed to adsorbed water on the sample surface [30,31].

From a comparison of Figs. 1 and 2 it follows that the main changes in the XPS data are in the $\mathrm{O} 1 \mathrm{~s}$ peak. The changes can be assigned to the effect of a water removal

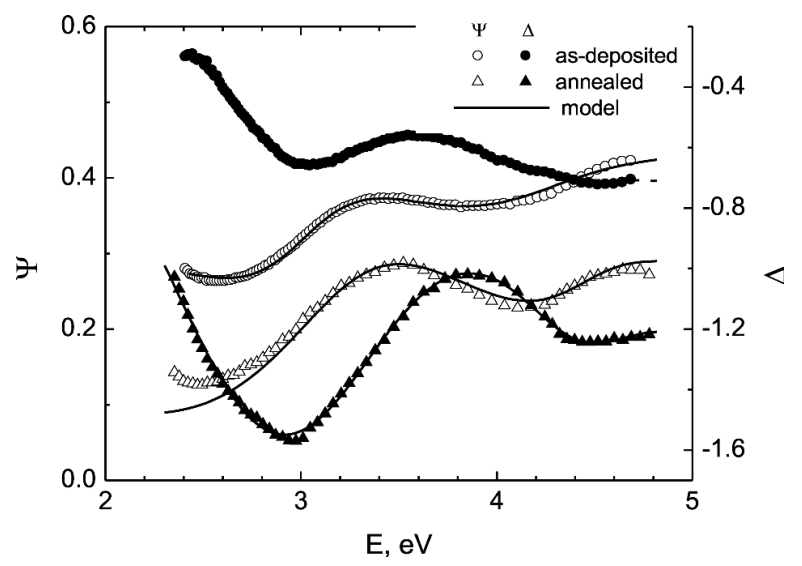

Fig. 3. Experimental (symbols) and modelled spectra of ellipsometric parameters $\Psi$ and $\Delta$ for as-prepared and annealed $\mathrm{V}_{2} \mathrm{O}_{5}$ films on glass at $75^{\circ}$ and $70^{\circ}$ angles of light incidence, respectively.

from the xerogel after the heat treatment. The XPS data allow us to conclude that sol-gel processed thin films on glass substrates are pure vanadium pentoxide.

Figure 3 illustrates the ellipsometric data of $\mathrm{V}_{2} \mathrm{O}_{5}$ films in the region of fundamental absorption band. Experimental spectra of ellipsometric parameters $\Psi$ and $\Delta$ have been described by contribution of three Lorentzian-type lines in the model of pseudodielectric function:

$$
\varepsilon(E)=\sum_{k} \frac{A_{k}}{E_{k}^{2}-E^{2}-\mathrm{i} E \Gamma_{k}},
$$

where $A_{k}, E_{k}$, and $\Gamma_{k}$ are the amplitude, energy, and width of the $k$ th line. As seen in Fig. 3, the model calculations adequately describe the experimental data. The values of Lorentzian parameters determined in the fitting procedure are presented in Table 2.

The spectra of pseudodielectric function that has been determined by fitting of ellipsometric data for asprepared and annealed $\mathrm{V}_{2} \mathrm{O}_{5}$ films are shown in Fig. 4. As seen there, the spectra show several characteristic features in the spectral range under investigation. These optical features agree well with the spectra of dielectric function of $\mathrm{V}_{2} \mathrm{O}_{5}$ single crystals in polarized light [32]. However, the absolute values of $\langle\varepsilon\rangle$ for sol-gel derived

Table 2. The parameters of Lorentzian-type lines (3) obtained from the fitting of experimental ellipsometric data in the region of fundamental absorption band for as-prepared and annealed $\mathrm{V}_{2} \mathrm{O}_{5}$ films.

\begin{tabular}{cccccccc}
\hline & \multicolumn{3}{c}{ As-prepared } & & \multicolumn{3}{c}{ Annealed } \\
\cline { 2 - 3 } \cline { 6 - 8 } & $A_{k}\left(\mathrm{eV}^{2}\right)$ & $E_{k}(\mathrm{eV})$ & $\Gamma_{k}(\mathrm{eV})$ & & $A_{k}\left(\mathrm{eV}^{2}\right)$ & $E_{k}(\mathrm{eV})$ & $\Gamma_{k}(\mathrm{eV})$ \\
\hline 1 & 6.19 & 3.02 & 0.85 & & 12.8 & 3.15 & 1.02 \\
2 & 10.0 & 4.26 & 1.41 & & 5.60 & 4.49 & 0.84 \\
3 & 61.6 & 6.02 & 3.04 & & 86.7 & 6.19 & 2.55 \\
\hline
\end{tabular}




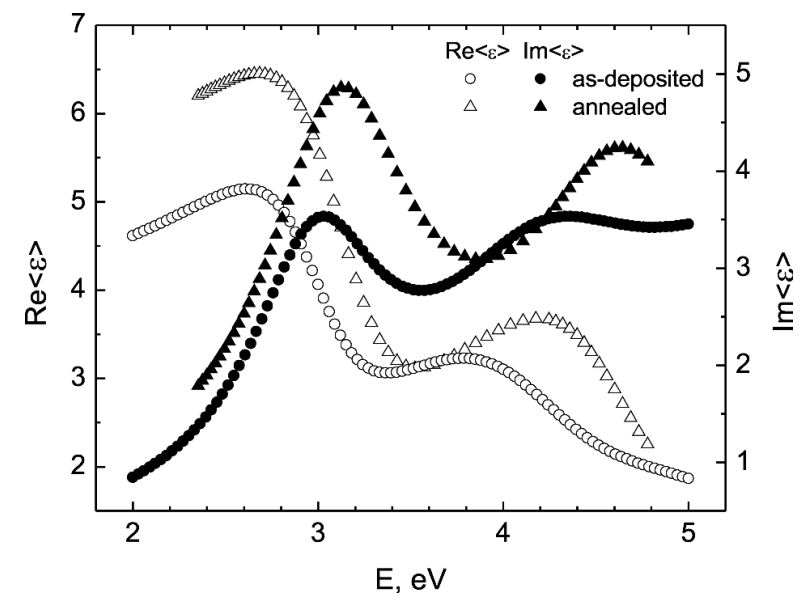

Fig. 4. Spectra of the complex pseudodielectric function $\langle\varepsilon\rangle$ of asprepared and annealed $\mathrm{V}_{2} \mathrm{O}_{5}$ films in the region of fundamental absorption band.

films are significantly $(\sim 3 \times)$ smaller than those of single crystals as has been observed also for nanocrystalline $\mathrm{V}_{2} \mathrm{O}_{5}$ films [15]. The variation of the spectra for $\mathrm{V}_{2} \mathrm{O}_{5}$ films of different crystallinity was demonstrated previously [15] and experimental ellipsometric data were interpreted in the frame of effective media approximation by inclusion of voids in model calculations. Taking into account these reference data [15] and relying on the maximum values of dielectric function at the $\sim 3 \mathrm{eV}$-peak, the sol-gel processed films that have been fabricated in the present work are polycrystalline with a certain $(\sim 50 \%)$ amount of amorphous $\mathrm{V}_{2} \mathrm{O}_{5}$. However, the crystallinity of the annealed films increases in comparison to that of as-prepared sample. It should also be emphasized that the higher energy peak is significantly reduced in amorphous $\mathrm{V}_{2} \mathrm{O}_{5}$ films [15] and is quite strong in the sol-gel processed films (Fig. 4). This is an additional argument for the assumption that the annealed sol-gel derived films under investigation are rather polycrystalline than amorphous.

The optical features of experimental spectra of $\mathrm{V}_{2} \mathrm{O}_{5}$ can be compared with the results of theoretical firstprinciples calculations by orthogonalized linear combination of atomic orbitals (OLCAO) method [33]. A particular feature of the $\mathrm{V}_{2} \mathrm{O}_{5}$ band structure is the occurrence of localized conduction bands with a width of $0.75 \mathrm{eV}$ originating from vanadium orbitals $3 \mathrm{~d}_{x y}$ and $3 \mathrm{~d}_{y z}$ with a slight mixing of oxygen $2 \mathrm{p}_{y}$ orbital. According to calculations [33], these bands are separated by $0.6 \mathrm{eV}$ from higher conduction bands. As a result, the calculated spectrum of imaginary part of the dielectric function $\operatorname{Im}(\varepsilon)$ is composed of two groups of peaks in the spectral range $E<5 \mathrm{eV}$, in agreement with previous optical $[15,32,33]$ and present ellipsometric data
(Fig. 4). Attention should be paid to a strong polarization dependence of $\operatorname{Im}(\varepsilon)$ spectra, in which the first group of peaks at $3 \mathrm{eV}$ is dominating at light polarized along the $a$ direction $(e \| a)$, whereas the second group at $4.5 \mathrm{eV}$ is mainly developed for $e \| c$. The polarization dependences qualitatively agree with the optical data for single crystals [32] though they are masked in the spectra of polycrystalline sol-gel processed films. However, the difference in optical spectra is clearly seen for light polarized along $a$ and $c$ axis of orthorhombic lattice for highly ordered nanocrystalline films [15].

Thus, the shape of dielectric function spectra in the fundamental absorption band of sol-gel processed films is in a qualitative agreement with the results of theoretical calculations [33] and optical reference data $[15,32]$. It should be emphasized that the second group of peaks, which has been resolved in $\mathrm{V}_{2} \mathrm{O}_{5}$ sol-gel derived films under investigation, is located at $\sim 4.5 \mathrm{eV}$, in a good agreement with theoretical calculations [33]. Annealing of as-prepared films leads to the blue shift $(\sim 0.15 \mathrm{eV})$ and increase of the peak at $\sim 3.0 \mathrm{eV}$ (see Table 2). The second effective band at $4.5 \mathrm{eV}$ has shown a similar behaviour under annealing as the first effective peak at $\sim 3.0 \mathrm{eV}$. As a result, two effective bands are better resolved in annealed $\mathrm{V}_{2} \mathrm{O}_{5}$ film. In addition, the width of the higher-energy band decreased significantly after thermal procedure.

The fundamental optical absorption edge in $\mathrm{V}_{2} \mathrm{O}_{5}$ is quite complicated. As follows from the band structure first-principles calculations [33], $\mathrm{V}_{2} \mathrm{O}_{5}$ is a semiconductor with indirect band gap at $\sim 2.0 \mathrm{eV}$ caused by the transitions from the top of the valence band at a point along the RZ direction to the bottom of the conduction band at $\Gamma$ point of the Brillouin zone. The indirect absorption edge $E_{\mathrm{gi}}=2.15 \mathrm{eV}$ was confirmed experimentally [5] from the spectral dependence of absorption coefficient $K=(A / E)\left(E-E_{\mathrm{gi}}\right)^{2}$, where $A$ is a constant proportional to the intensity of indirect optical transitions. Below indirect gap, the exponential decrease of absorption coefficient was observed [5]. The direct band gap at the $\Gamma$ point was also predicted from theoretical calculations [33]. From the spectral dependence of absorption coefficient $K(E)$ caused by direct optical transitions $K=(A / E)\left(E-E_{\text {gd }}\right)^{1 / 2}$, the direct band gap $E_{\mathrm{gd}}$ equal to 2.49 and $2.42 \mathrm{eV}$ was determined [11] for as-grown and annealed at $473 \mathrm{~K} \mathrm{~V}_{2} \mathrm{O}_{5}$ sol-gel films, respectively.

The present data confirmed the complex nature of the main absorption edge in $\mathrm{V}_{2} \mathrm{O}_{5}$ films. A steep rise of absorption coefficient was observed at $\sim 2.2 \mathrm{eV}$ in agreement with the data $\left(E_{\mathrm{g}}=2.24 \mathrm{eV}\right.$ [34]) for sput- 


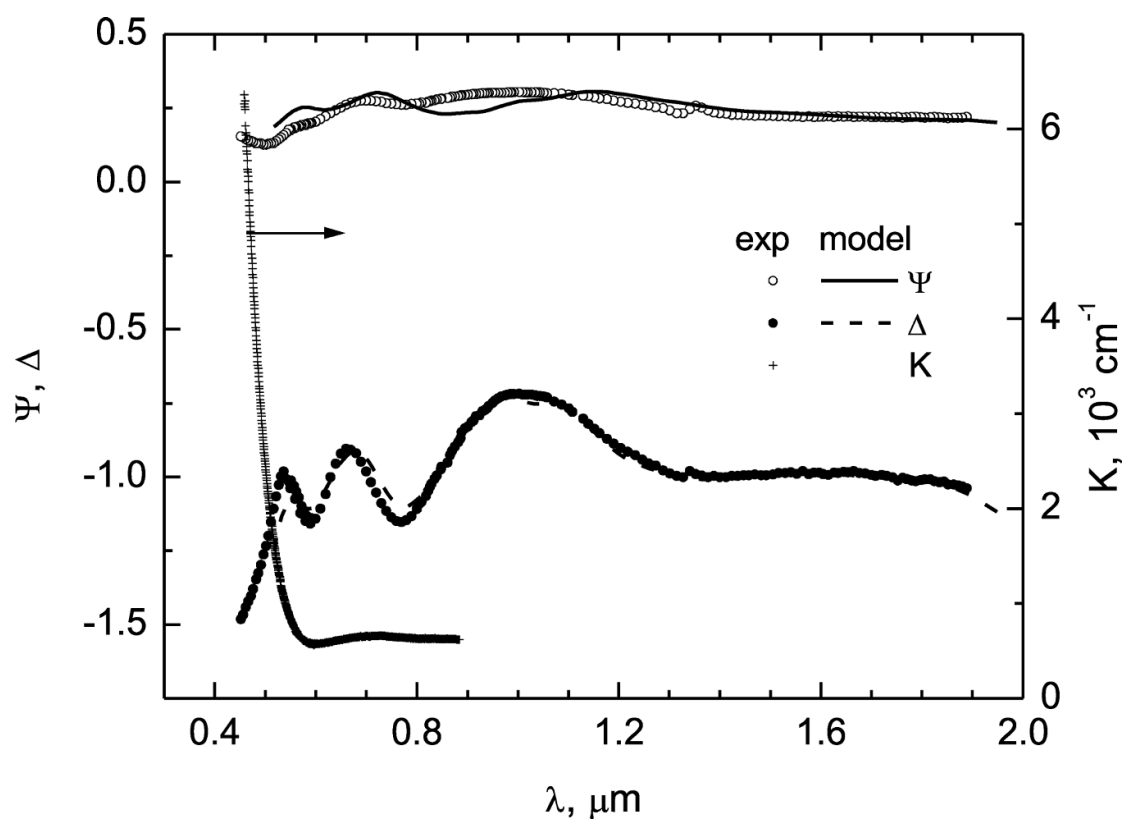

Fig. 5. Experimental (symbols) and modelled (curves) ellipsometric data and the absorption spectrum of annealed $\mathrm{V}_{2} \mathrm{O}_{5}$ films in the near infrared region.

tered films of orthorhombic symmetry. A spectral dependence of $K(E)$ was found to be similar to that determined previously [11] as well as the red shift $(\sim 0.1 \mathrm{eV})$ of the absorption edge for annealed films. Thus, the opposite shift of the absorption edge and the main peak in $\varepsilon(E)$ at $\sim 3 \mathrm{eV}$ under annealing indicates that different energy levels are involved in the corresponding optical transitions.

In the low photon energy region $0.6-2.0 \mu \mathrm{m}$, the oscillatory pattern is clearly resolved for annealed sample (Fig. 5). This feature is due to the interference in the $\mathrm{V}_{2} \mathrm{O}_{5}$ film. The occurrence of interference pattern indicates a satisfactory quality and homogeneity of the sample which has been significantly increased after the thermal annealing procedure. It is known [8] that the film stoichiometry depends on film thickness of magnetron sputtered vanadium oxide thin films and a critical thickness of $d_{\mathrm{cr}} \sim 250 \mathrm{~nm}$ has been determined. The completely stoichiometric $\mathrm{V}_{2} \mathrm{O}_{5}$ films of $d>d_{\text {cr }}$ were grown in [7] independently of the oxygen partial pressure.

The experimental spectra of ellipsometric parameters $\Psi(E)$ and $\Delta(E)$ were described by multilayer model [22]. The contribution of 5 to 10 layers should be modelled to fit the calculation results to experimental ellipsometric data (Fig. 5). In the fitting procedure the contribution of Lorentzian-type lines was modelled with the values of the energy $E_{k}$ and width $\Gamma_{k}$ determined from ellipsometric data in the fundamental ab- sorption band (Fig. 4, Table 2). However, the amplitudes of the lines in each layer were adjustable parameters for simulating the influence of voids and crystallinity. In this simple model the experimental ellipsometric data were satisfactorily described by model calculations.

The spectra of refraction index of each layer for annealed $\mathrm{V}_{2} \mathrm{O}_{5}$ sol-gel processed film are shown in Fig. 6. The effective refraction index $n_{\text {eff }}$ is calculated in the effective media approximation [35] by averaging the dielectric functions for each layer: $\varepsilon_{\text {eff }}=\sum_{i} f_{i} \varepsilon_{i}$, where $f_{i}=d_{i} / d$ represents the volume fraction of each layer and hence the contribution to the average dielectric function. As seen from Fig. 6, the values of refraction index in various layers of sol-gel processed film are spread in a broad range of 1.7-2.5, indicating a polycrystalline nature of porous $\mathrm{V}_{2} \mathrm{O}_{5}$ samples. The value of effective refraction index increased from $\sim 2.1$ to $\sim 2.5$ at 2.0 and $0.7 \mu \mathrm{m}$, respectively.

As noted above, the refractive index of sputtered $\mathrm{V}_{2} \mathrm{O}_{5}$ thin films depended strongly on technological procedure [7] and varied in the range 2.1-2.5 in the near IR region. The Sellmeier law fit gives the value $n_{\infty}=$ 2.18 [5] from interference pattern of $\mathrm{V}_{2} \mathrm{O}_{5}$ films. On the other hand, sputtered $\mathrm{V}_{2} \mathrm{O}_{5}$ films are textured [5]. The $\langle 001\rangle$ axis of crystallites of orthorhombic $\mathrm{V}_{2} \mathrm{O}_{5}$ lattice (in notations of the space group Pmnm [36]) is oriented perpendicularly to substrate. From the optical data [33], obtained on thin platelets of $\mathrm{V}_{2} \mathrm{O}_{5}$ single 


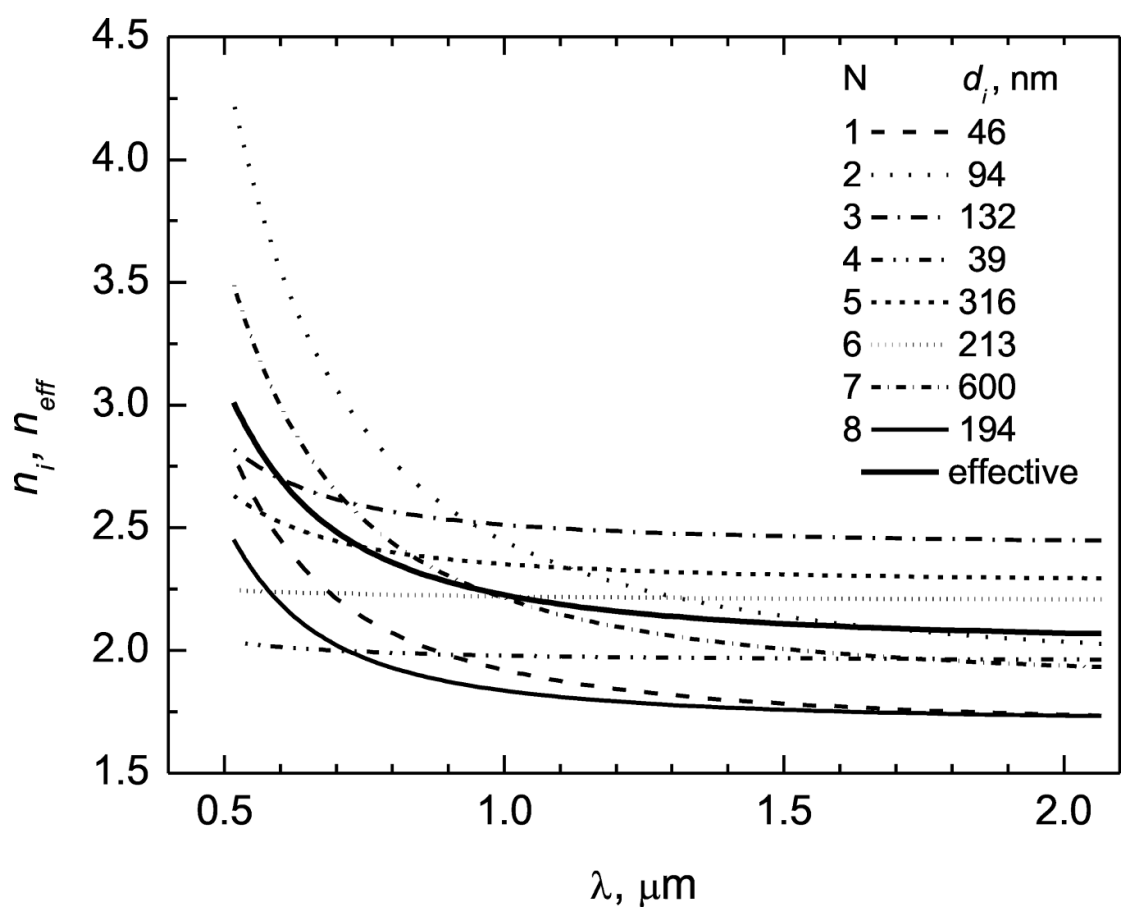

Fig. 6. Spectra of refraction index for modelled layers in annealed $\mathrm{V}_{2} \mathrm{O}_{5}$ film. Layers $N=1$ and $N=8$ are located at the surface of the film and at the substrate, respectively. Thick curve shows the data for effective refraction index.

crystals with developed $a c$ planes, it follows that $n_{a}=$ 2.5 and $n_{b}=n_{c}=2.1$ at $1 \mathrm{eV}$ with a slight increase due to dispersion in the region of optical transparency. Thus, the evaluated effective refraction index for investigated sol-gel processed films agrees well with the reference data for $\mathrm{V}_{2} \mathrm{O}_{5}$.

In the transparency region the residual absorption of investigated films was quite high $\left(\sim 600 \mathrm{~cm}^{-1}\right)$, indicating a relatively high concentration of native defects. Even higher extinction values followed from the fitting of ellipsometric data in the near IR region. It should be noted that two absorption peaks at 1.2 and $1.7 \mathrm{eV}$ due to optical transitions involving native defect levels were observed [5] in sputtered $\mathrm{V}_{2} \mathrm{O}_{5}$ films. Some structure was also observed in the films under investigation. However, they were considerably masked by interference pattern. Annealing procedure has improved the quality of the film but the optical transmission was decreased, as also is observed for other xerogel films [4]. It should be noted that increase of absorption was found with an increase of $\mathrm{VO}_{2}$ admixture in sputtered films [34]. In the region of transparency the optical properties of gel films are particularly sensitive to external factors, e.g., the influence of electric field [4] leading to electrochromic effect.

\section{Conclusions}

On the basis of experimental results and reference data it is concluded that the changes in the optical spectra observed after thermal annealing are mainly due to the improvement of the structure of thin $\mathrm{V}_{2} \mathrm{O}_{5}$ films because of removal of water from as-prepared samples. The XPS and optical data have shown that thermal treatment has strongly influenced the optical transitions involving both localized and higher-lying conduction bands.

\section{Acknowledgements}

The authors wish to thank Agency for International Science and Technology Development Programmes in Lithuania (grant No.31V-86) and the Lithuanian State Science and Studies Foundation for financial support of this work.

\section{References}

[1] S. Velusamy and T. Punniyamurthy, Novel vanadiumcatalyzed oxidation of alcohols to aldehydes and ketones under atmospheric oxygen, Org. Lett. 6, 217-219 (2004). 
[2] W. Zhang and H. Yamamoto, Vanadium-catalyzed asymmetric epocidation of homoallylic alcohols, J. Am. Chem. Soc. 129, 286-287 (2007).

[3] Z. Liu, G. Fang, Y. Wang, Y. Bai, and K.-L. Yao, Laserinduced colouration of $\mathrm{V}_{2} \mathrm{O}_{5}$, J. Phys. D 33, 2327-2332 (2000).

[4] A.L. Pergament, E.L. Kazakova, and G.B. Stefanovich, Optical and electrical properties of vanadium pentoxide xerogel films: Modification in electric field and the role of ion transport, J. Phys. D 35, 2187-2197 (2002).

[5] M. Benmoussa, E. Ibnouelghazi, A. Bennouna, and E.L. Ameziane, Structural, electrical and optical properties of sputtered vanadium pentoxide thin films, Thin Solid Films 265, 22-28 (1995).

[6] M.G. Krishna and A.K. Bhattacharya, Optical and structural properties of bias sputtered vanadium pentoxide thin films, Vacuum 48, 879-882 (1997).

[7] M.G. Krishna, Y. Debauge, and A.K. Bhattacharya, $\mathrm{X}$-ray photoelectron spectroscopy and spectral transmittance study of stoichiometry in sputtered vanadium oxide films, Thin Solid Films 312, 116-122 (1998).

[8] L.A. Ryabova, I.A. Serbinov, and A.S. Darevsky, Preparation and properties of pyrolysis of vanadium oxide films, J. Electrochem. Soc. 119, 427-429 (1972).

[9] J. Livage, Synthesis of polyoxovanadates via "chimie douce", Coord. Chem. Rev. 178-180, 999-1018 (1998).

[10] Y. Dachuan, X. Niakan, Z. Jingyu, and Z. Xiulin, High quality vanadium dioxide films prepared by an inorganic sol-gel method, Mater. Res. Bull. 31, 335-340 (1996).

[11] Z.S. El Mandouh and M.S. Selim, Physical properties of vanadium pentoxide sol gel films, Thin Solid Films 371, 259-263 (2000).

[12] J.-J. Legendre and J. Livage, Vanadium pentoxide gels: I. Structural study by electron diffraction, J. Colloid Interf. Sci. 94, 75-83 (1983).

[13] J.-J. Legendre, P. Aldebert, N. Baffier, and J. Livage, Vanadium pentoxide gels: II. Structural study by X-ray diffraction, J. Colloid Interf. Sci. 94, 84-89 (1983).

[14] J. Livage, O. Pelletier, and P. Davidson, Vanadium pentoxide sol and gel mesophases, J. Sol-Gel Sci. Technol. 19, 275-278 (2000).

[15] M. Lasurdo, G. Bruno, D. Barreca, and E. Tondello, Dielectric function of $\mathrm{V}_{2} \mathrm{O}_{5}$ nanocrystalline films by spectroscopic ellipsometry: Characterization of microstructure, Appl. Phys. Lett. 77, 1129-1131 (2000).

[16] J. Bullot, P. Cordier, O. Gallais, M. Gauthier, and F. Babonneau, Thin layers deposited from $\mathrm{V}_{2} \mathrm{O}_{5}$ gels II. An optical absorption study, J. Non-Cryst. Solids 68, 135-146 (1984).

[17] N.T.B. Bay, P.M. Tien, S. Badilescu, Y. Djaoued, G. Bader, F.E. Girouard, and V.-V. Truong, ATR/FTIR study of vanadium pentoxide gel films on semiconductor substrates, Appl. Spectrosc. 49, 1279-1281 (1995).
[18] E. Müller, Herstellung kolloider Vanadinsäure nach einer neuen Dispersionsmethode, Z. Chem. Ind. Kolloide 8, 302-303 (1911) [Colloid Polymer Sci., in German].

[19] V.L. Volkov, G.S. Zakharova, and V.M. Bondarenka, Simple and Complicated Xerogels of Polyvanadates (Ural Branch of Russian Academy of Sciences, Ekaterinburg, 2001) [in Russian].

[20] M. Benmoussa, A. Outzourhit, A. Bennouna, and E.L. Ameziane, Optical constants and electrochromic properties of sol-gel $\mathrm{V}_{2} \mathrm{O}_{5}$ thin films, J. Phys. IV 123, 41-45 (2005).

[21] J. Livage, G. Guzman, F. Beteille, and P. Davidson, Optical properties of sol-gel derived vanadium oxide films, J. Sol-Gel Sci. Technol. 8, 857-865 (1997).

[22] V. Vaičikauskas, G.-J. Babonas, Z. Kuprionis, G. Niaura, and V. Šablinskas, Paviršiaus optine spektroskopija (TEV, Vilnius, 2008) [Optical Spectroscopy of Surface, in Lithuanian].

[23] G.J. Babonas, A. Niilisk, A. Reza, A. Matulis, and A. Rosental, Spectroscopic ellipsometry of $\mathrm{TiO}_{2} / \mathrm{Si}$, Proc. SPIE 5122, 50-55 (2003).

[24] D.E. Aspnes, Approximate solution of ellipsometric equations for optically biaxial crystals, J. Opt. Soc. Am. 70, 1275-1277 (1980).

[25] R.M.A. Azzam and N.M. Bashara, Ellipsometry and Polarized Light (North-Holland, Amsterdam, 1977).

[26] G.J. Babonas, A. Reza, I. Simkiene, J. Sabataityte, M. Baran, R. Szymczak, U.O. Karlsson, and A. Suchodolskis, Optical properties of Fe-doped silica films on Si, Appl. Surf. Sci. 22, 5391-5394 (2006).

[27] J.F. Mouder, W.F. Stiskle, P.E. Sobol, and K.D. Bomben, Handbook of X-ray Photoelectron Spectroscopy (Eden Prairie, USA, 1995).

[28] G. Hopfengartner, D. Borgman, I. Rademacher, G. Wedler, E. Hums, and G.W. Spitznagell, XPS studies of oxidic model catalysts: Internal standards and oxidation numbers, J. Electron Spectrosc. Related Phenom. 63, 91-116 (1993).

[29] M. Demeter, M. Neumann, and W. Reichelt, Mixedvalence vanadium oxidies studied by XPS, Surf. Sci. 454-456, 41-44 (2000).

[30] V.I. Nefedov, D. Gati, B.E. Dzhurinskii, N.P. Sergushin, and Ya.V. Salyn, Simple and coordination compounds. An X-ray photoelectron spectroscopic study of certain oxides, Russian J. Inorg. Chem. 20, 2307-2314 (1975).

[31] A.M. Beccaria, G. Poggi, and G. Castello, Influence of passive film composition and sea water pressure on resistance to localised corrosion of some stainless steels in sea water, British Corrosion J. 30, 283-287 (1995).

[32] V.G. Mokerov, V.L. Makarov, V.B. Tulvinskii, and A.R. Begishev, Opticheskie svoistva pyatiokisi vanadiya $\mathrm{v}$ intervale energii fotonov ot 2 do $14 \mathrm{eV}$, Opt. Spektrosk. [Opt. Spectrosc. (USSR)] 40, 104-110 (1976) [Optical properties of vanadium pentoxide in 
the $2-14 \mathrm{eV}$ photon energy interval, in Russian].

[33] J.C. Parker, D.J. Lam, Y.-N. Xu, and W.Y. Ching, Optical properties of vanadium pentoxide determined from ellipsometry and band-structure calculations, Phys. Rev. B 42, 5289-5293 (1990).

[34] E.E. Chain, Optical properties of vanadium dioxide and vanadium pentoxide thin films, Appl. Opt. 30, 2782-
2787 (1991).

[35] U. Kreibig and M. Vollmer, Optical Properties of Metal Clusters (Springer, Berlin, 1995).

[36] H.G. Bachmann, F.R. Achmed, and W.H. Barnes, The crystal structure of vanadium pentoxide, Z. Kristallogr. 115, 110-131 (1961).

\title{
VANADŽIO PENTOKSIDO SLUOKSNIŲ, PAGAMINTŲ ZOLIO-GELIO TECHNOLOGIJA, RENTGENO FOTOELEKTRONINIAI SPEKTRAI IR OPTINĖS SAVYBĖS
}

\author{
V. Bondarenka ${ }^{\text {a }}$, S. Kačiulis ${ }^{\text {b }}$, Z. Martūnas ${ }^{\text {a }}$, A. Rėza ${ }^{\text {a }}$, G.J. Babonas ${ }^{\text {a }}$, A. Pašiškevičius ${ }^{\text {a }}$ \\ ${ }^{a}$ Puslaidininkiu fizikos institutas, Vilnius, Lietuva \\ ${ }^{\mathrm{b}}$ Nanosandaros medžiagu tyrimo institutas, Monterotondo Scalo, Italija
}

\begin{abstract}
Santrauka
Vanadžio pentoksido kserogeliai paruošti naudojant zolio-gelio technologiją. Gauti kserogeliai buvo kaitinami iki $580 \mathrm{~K}$, siekiant pašalinti iš jų surištą vandenį. Kserogelių ir plonųjų sluoksnių cheminè sudètis tirta naudojant Rentgeno fotoelektronų spektroskopijos (RFS) metodą. RFS tyrimo rezultatai parodè, kad technologinio proceso metu tikrai susiformavo vanadžio pentoksido plonieji sluoksniai. Pagrindiniai RFS spektru pokyčiai, po terminio apdo-
\end{abstract}

rojimo pašalinant vandeni iš kserogelio, vyko $\mathrm{O} 1 \mathrm{~s}$ smailèje. $\mathrm{V}_{2} \mathrm{O}_{5}$ plonųjų sluoksnių optinès savybės buvo tirtos optinès absorbcijos ir spektroskopinès elipsometrijos metodais. Elipsometriniai matavimai atlikti $0,5-5,0 \mathrm{eV}$ fotonų energijos ruože esant $300 \mathrm{~K}$ temperatūrai. Pastebèti ir išanalizuoti optinių spektrų pokyčiai po kserogelio bandinių atkaitinimo. Gauti duomenys parodè, $\mathrm{kad}_{2} \mathrm{O}_{5}$ sluoksnių terminis apdorojimas stipriai veikia optinius šuolius tarp lokalizuotų lygmenų ir aukščiau esančių laidumo juostų. 